\title{
Sensory and physic-chemical properties of wheat bread prepared with apple pomace
}

\author{
Elvira A. Pyanikova*, Anna E. Kovaleva, Maria A. Zaikina, and Aleksey G. Belyaev \\ SouthWest State University, Technology and Expertise of Goods, 305040, Kursk,50 years of October \\ Av., 94, Russia
}

\begin{abstract}
The influence of secondary apple raw materials (frozen apple pomace) on organoleptic and physicochemical indicators of the quality of wheat bread has been studied. The traditional recipe of wheat bread was taken as a basis. In this recipe for the sample of bread No. 1, a part of the premium wheat flour was replaced with $25 \%$ rice flour and $10 \%$ frozen apple pomace. In the sample of bread No. 2, a part of the premium wheat flour was replaced with $12.5 \%$ rice flour and $10 \%$ fresh frozen apple pomace. For the organoleptic assessment, a five-point scale for assessing the quality of bread was developed, in which the maximum number of points up to5 was assigned to each indicator. According to the results of the study of the organoleptic indicators of the quality of the developed samples of bread using a point scale, it was found that they exceeded the control sample. The best was the sample with fresh frozen apple pomace $10 \%$ and rice flour in the amount of $12.5 \%$. In terms of physical and chemical indicators, the developed samples of wheat bread enriched with apple raw materials meet the regulatory requirements.
\end{abstract}

\section{Introduction}

There was a general trend recently toward increasing the nutritional value of bakery products like bakery products strengthening fiber, as the bakery products are consumed widely in the international food markets [1].

Bread is a staple diet that is consumed daily, and its quality and sensory attributes are highly considered by consumers [2].

It can act as an excellent source of energy. Bread is a carrier of folate, copper, thiamine, zinc, iron, phytic acid, minerals [3].

Bread can also be a good carrier of phenolic antioxidants and fiber polysaccharides in high concentrations [4], which are very rich in apple raw materials.

Apple is an important nutritional crop that is mostly consumed as fresh fruit; however, a small proportion of apples are processed into cooked slices, juices and jellies [5]. This produces a huge amount of pomace, which is a waste of juice production.

Apple pomace is mainly composed of skin and flesh with a low proportion of seeds and stems [6].

* Corresponding author: pyanikovaelvira@yandex.ru 
Apple pomace is used as animal food as it is a good source of digestible fiber, pectin and phenolic compounds while its use as compost is not environmentally friendly. The phenolic profile of apple pomace includes hydroxycinnamic acids, flavan-3-ols, anthocyanins, flavonols and dihydrochalcones [7].

Apple pomace is a rich source of natural (PPs) with remarkable antioxidant properties. Excellent reviews are devoted to the health related effects of PPs in human nutrition [8-10].

Meanwhile, apple pomace is a rich source of biologically active substances - vitamins $\mathrm{C}, \mathrm{P}, \mathrm{E}, \beta$-carotene, triterpene compounds, vitamins of group $\mathrm{B}$, mineral elements (after squeezing the juice, almost half of the total amount of essential mineral elements remains in the pomace), dietary fiber, including pectin substances [11]. Dietary fibers from various sources are used to replace wheat flour in the preparation of bakery products.

\section{Materials and methods}

\subsection{Materials}

Baking wheat flour of the highest grade produced by Ryazanochka (Russia), rice flour produced by Kudesnitsa (Russia).

Fresh pressed yeast, salt and corn oil were purchased from the local market.

Apple pomace is obtained as a waste in the production of apple juice and is subject to shock freezing.

\subsection{Determination of the biochemical activity of yeast}

The biochemical activity of yeast is of great technological importance in the production of bread. The structure of the dough, the volume and shape of the finished products depend on the properties of the yeast [12-14].

To study the biochemical activity of yeast, a nutrient mixture was prepared. Water at a temperature of $35^{\circ} \mathrm{C}$ was poured over thawed apple pomace and stirred to ensure a more complete extraction of soluble substances. Then yeast was added to the mixture and the mixture was kept at $33-35{ }^{\circ} \mathrm{C}$ for $30 \mathrm{~min}$. The lifting force of the yeast improved from 12 minutes (no activation) to 7 minutes. Studies have shown that increasing the dose of raw apple pomace is impractical [15].

To determine the effect of the supplement on the condition and activity of the yeast, a number of studies have been carried out. The lifting force of the yeast was determined by the accelerated method. Counting the number of cells of microorganisms under a microscope was carried out using a Tom-Goryaev camera.

\subsection{Bread making technology and recipe}

Apple pomace was previously thawed and soaked in a mixture of vegetable oil and warm water (water temperature $28-30^{\circ} \mathrm{C}$ ). The mixture was constantly stirred until it became a homogeneous consistency. Then it was allowed to stand for 15-20 minutes. The remaining ingredients (flour, salt, yeast) were mixed at the same time. After that, the mixture with pomace was added to the dough.

After kneading, the dough was fermented for 5-7 minutes. In this case, the dough temperature rose to $30^{\circ} \mathrm{C}$. Then the kneading was carried out, after which the fermentation process continued for another 5-7 minutes.

To increase the acidity of bread and reduce the fermentation process, apple raw materials are introduced into the recipe. This made it possible to shorten the fermentation 
process. Then they were poured into molds. The bread for proofing was placed in a special chamber for 20 minutes. The proofing process was carried out at a temperature of 34-35 ${ }^{\circ} \mathrm{C}$. As a result, the dough increased in volume. Bread was baked at a temperature of 195$205{ }^{\circ} \mathrm{C}$. The baking time was 20 minutes. The baked bread was gradually cooled at room temperature.

Bread recipes are presented in table 1.

Table1. Breadrecipe.

\begin{tabular}{|l|c|c|c|}
\hline \multicolumn{1}{|c|}{ Raw material composition } & Controlsample & Sample №1 & Sample №2 \\
\hline High-grade baking wheat flour, $g$ & 160 & 120 & 140 \\
\hline Riceflour, g & - & 40 & 20 \\
\hline Pressedyeast, g & 5,5 & 5,5 & 5,5 \\
\hline Drinkingwater, $\mathrm{ml}$ & 110 & 110 & 110 \\
\hline Vegetableoil, ml & 10 & 10 & 10 \\
\hline Applepomace, g & - & 30 & 30 \\
\hline Tablesalt, g & 2,5 & 2,5 & 2,5 \\
\hline Granulated sugar, $\mathrm{g}$ & 2,5 & - & - \\
\hline
\end{tabular}

\subsection{Physicalpropertiesofbread}

The bread weight (g) was determined after cooling for 60 minutes. according to the techniques described in AOAC (2000) [16].

Moisture content and acidity were determined on the day of baking according to the method described in AOAC (2000).

The content of iron in food was determined using a spectrophotometer, based on measuring the colour intensity of a solution of a complex compound of ferrous iron with orthophenanthroline.

To determine phosphorus in bread, the method of dry or wet mineralisation was used.

\subsection{Sensory characteristics of bread}

Evaluation of the sensory properties of the bread was carried out using expert and organoleptic methods. The expert method is based on the fact that an expert assigns a certain point to each of the criteria [17]. The sensory properties of bread were assessed according to the developed five-point scale: 5 - excellent quality; 4 - good quality; 3 - not very good quality; 2 - poor quality.

The scale is presented in Table 2. 
Table 2. Scale scoring the quality of bread

\begin{tabular}{|c|c|c|c|c|}
\hline \multirow[t]{2}{*}{ Indicators } & \multicolumn{4}{|c|}{ Points } \\
\hline & 5 & 4 & 3 & 2 \\
\hline Form & $\begin{array}{l}\text { Rounded, oval or } \\
\text { oblong-oval, not } \\
\text { undefined, } \\
\text { without imprints }\end{array}$ & $\begin{array}{l}\text { Rounded, oval or } \\
\text { oblong-oval, not } \\
\text { undefined, with small } \\
\text { imprints. }\end{array}$ & $\begin{array}{l}\text { Rounded, oval or } \\
\text { oblong-oval, } \\
\text { slightly } \\
\text { undefined, with } \\
\text { imprints }\end{array}$ & $\begin{array}{l}\text { Does not match } \\
\text { the bread shape, } \\
\text { undefined, with a } \\
\text { fallen crust }\end{array}$ \\
\hline Surface & $\begin{array}{l}\text { Free from large } \\
\text { cracks or tears, } \\
\text { smooth or rough. } \\
\text { Allowed: mealy } \\
\text { for hearth bread }\end{array}$ & $\begin{array}{l}\text { Smooth or rough, with } \\
\text { small cracks and } \\
\text { breaks, } \\
\text { Allowed: mealy }\end{array}$ & $\begin{array}{l}\text { Rough, glossless } \\
\text { surface, with } \\
\text { cracks and } \\
\text { dents.Allowed: } \\
\text { mealyfallencrust }\end{array}$ & $\begin{array}{l}\text { Rough, glossless } \\
\text { surface, with large } \\
\text { cracks and } \\
\text { explosions.Peeling } \\
\text { of crust from } \\
\text { crumb }\end{array}$ \\
\hline Colour & $\begin{array}{l}\text { Light yellow to } \\
\text { dark brown with } \\
\text { even distribution } \\
\text { of supplements }\end{array}$ & $\begin{array}{l}\text { Light brown to dark } \\
\text { brown with slightly } \\
\text { uneven distribution of } \\
\text { supplements }\end{array}$ & $\begin{array}{l}\text { Pale brown to } \\
\text { dark brown with } \\
\text { uneven } \\
\text { distribution of } \\
\text { supplements, } \\
\text { burnt }\end{array}$ & $\begin{array}{l}\text { Pale grey or } \\
\text { brown-grey to } \\
\text { black with uneven } \\
\text { distribution of } \\
\text { supplements }\end{array}$ \\
\hline Bakedgoods & $\begin{array}{l}\text { Baked, not damp } \\
\text { to the } \\
\text { touch.Elastic, } \\
\text { after light } \\
\text { pressure with } \\
\text { your fingers, the } \\
\text { crumb should } \\
\text { return to its } \\
\text { original shape }\end{array}$ & $\begin{array}{l}\text { Not damp to the } \\
\text { touch.After light } \\
\text { pressure with your } \\
\text { fingers, the crumb } \\
\text { does not return to its } \\
\text { original shape }\end{array}$ & $\begin{array}{l}\text { Wet to the } \\
\text { touch.After light } \\
\text { pressure with } \\
\text { your fingers, the } \\
\text { crumb does not } \\
\text { return to its } \\
\text { original shape }\end{array}$ & $\begin{array}{l}\text { Not baked, moist } \\
\text { to the touch.Not } \\
\text { elastic, after light } \\
\text { pressure with } \\
\text { fingers, the crumb } \\
\text { does not return to } \\
\text { its original shape }\end{array}$ \\
\hline Mixture & $\begin{array}{l}\text { No lumps and } \\
\text { traces of } \\
\text { impurities. }\end{array}$ & $\begin{array}{l}\text { Small lumps are } \\
\text { observed, without } \\
\text { traces of impurities }\end{array}$ & $\begin{array}{l}\text { Small lumps and } \\
\text { traces of } \\
\text { impurities are } \\
\text { observed }\end{array}$ & $\begin{array}{l}\text { Lumpyandpoorly } \\
\text { mixed }\end{array}$ \\
\hline Porosity & $\begin{array}{l}\text { Developed, } \\
\text { without holes and } \\
\text { compaction. }\end{array}$ & $\begin{array}{l}\text { Developed, without } \\
\text { holes and compaction. }\end{array}$ & $\begin{array}{l}\text { With a lot of } \\
\text { holes, with little } \\
\text { compaction at the } \\
\text { crust }\end{array}$ & $\begin{array}{l}\text { Undeveloped, } \\
\text { with large holes } \\
\text { and / or severe } \\
\text { crust compaction }\end{array}$ \\
\hline Taste & $\begin{array}{l}\text { Characteristic of } \\
\text { this type of } \\
\text { product, without } \\
\text { any strange taste. }\end{array}$ & $\begin{array}{l}\text { Weakly expressed taste } \\
\text { of this product, } \\
\text { without strange } \\
\text { aftertaste }\end{array}$ & $\begin{array}{l}\text { Poorly expressed } \\
\text { taste of this } \\
\text { product with an } \\
\text { added additive, } \\
\text { with a strange } \\
\text { taste }\end{array}$ & $\begin{array}{l}\text { Uncharacteristic } \\
\text { of this type of } \\
\text { product with a } \\
\text { pronounced } \\
\text { extraneous taste } \\
\text { not typical of } \\
\text { additionally } \\
\text { introduced raw } \\
\text { materials }\end{array}$ \\
\hline Smell & $\begin{array}{l}\text { Specific to this } \\
\text { type of product, } \\
\text { without any } \\
\text { strange smell }\end{array}$ & $\begin{array}{l}\text { Weak smell of this } \\
\text { product, no strange } \\
\text { smell }\end{array}$ & $\begin{array}{l}\text { Poor smell of this } \\
\text { product, with a } \\
\text { strange smell }\end{array}$ & $\begin{array}{l}\text { Uncharacteristic } \\
\text { for this type of } \\
\text { product, with a } \\
\text { strange, musty } \\
\text { and mouldy smell }\end{array}$ \\
\hline
\end{tabular}




\section{Results and discussion}

Using a point scale (Table 2), each taster completed the card. The obtained results were processed and based on them a test report was drawn up. Description and average values of organoleptic indicators of the quality of bread samples are given in table 3 .

Table 3. Average values of organoleptic indicators of the quality of bread samples

\begin{tabular}{|c|c|c|c|}
\hline Nameofsamples & Controlsample & SampleNo.1 & SampleNo.2 \\
\hline $\begin{array}{l}\text { Appearance } \\
\text { Form }\end{array}$ & $\begin{array}{l}\text { product of the correct } \\
\text { shape;there are lateral } \\
\text { explosions } \\
\text { ( } 4.2 \text { points) }\end{array}$ & $\begin{array}{l}\text { product of regular } \\
\text { shape, with a slightly } \\
\text { convex upper crust } \\
\text { (4.9 points) }\end{array}$ & $\begin{array}{l}\text { product of the correct } \\
\text { shape, with a convex } \\
\text { upper crust } \\
\text { ( } 4.8 \text { points })\end{array}$ \\
\hline Surface & $\begin{array}{c}\text { rough, withexplosions } \\
\text { (3.8 points) }\end{array}$ & $\begin{array}{l}\text { rough, without cracks } \\
\text { and explosions } \\
\text { (4.8 points) }\end{array}$ & $\begin{array}{l}\text { rough, without cracks } \\
\text { and explosions } \\
\text { (4.6 points) }\end{array}$ \\
\hline Colour & $\begin{array}{l}\text { light brown, with slight } \\
\text { burnt;crumb color } \\
\text { white } \\
\text { (3.6 points) }\end{array}$ & $\begin{array}{l}\text { light brown; white } \\
\text { crumb with a grayish } \\
\text { tint } \\
\quad \text { (4.9 points) } \\
\end{array}$ & $\begin{array}{l}\text { light brown; white } \\
\text { crumb with a slight } \\
\text { grayish tint } \\
\text { (4.8 point) }\end{array}$ \\
\hline $\begin{array}{l}\text { The crumbs: } \\
\text { Baked goods }\end{array}$ & $\begin{array}{l}\text { baked, not wet to the } \\
\text { touch, elastic; after } \\
\text { light pressure with } \\
\text { your fingers, the crumb } \\
\text { takes on its original } \\
\text { shape (5 points) }\end{array}$ & $\begin{array}{l}\text { baked, not wet to the } \\
\text { touch, elastic; after } \\
\text { light pressure with } \\
\text { your fingers, the } \\
\text { crumb takes on its } \\
\text { original shape } \\
\text { ( } 5 \text { points) } \\
\end{array}$ & $\begin{array}{l}\text { baked, not wet to the } \\
\text { touch, elastic; after } \\
\text { light pressure with } \\
\text { your fingers, the } \\
\text { crumb takes on its } \\
\text { original shape } \\
\text { (5 points) } \\
\end{array}$ \\
\hline Mixture & $\begin{array}{l}\text { without lumps and } \\
\text { traces of impurities } \\
\text { ( } 5 \text { points) }\end{array}$ & $\begin{array}{l}\text { without lumps and } \\
\text { traces of impurities } \\
\text { ( } 5 \text { points) }\end{array}$ & $\begin{array}{l}\text { without lumps and } \\
\text { traces of impurities } \\
\text { ( } 5 \text { points) }\end{array}$ \\
\hline Porosity & $\begin{array}{l}\text { developed, } \\
\text { presence of large } \\
(4.0 \text { points })\end{array}$ & $\begin{array}{c}\text { developed, fewholes } \\
\text { (4.6 points) }\end{array}$ & $\begin{array}{l}\text { developed, } \\
\text { withoutholes } \\
\text { (5 points) }\end{array}$ \\
\hline Taste & $\begin{array}{l}\text { pleasant, typical of } \\
\text { wheat bread } \\
\text { (5 points) }\end{array}$ & $\begin{array}{l}\text { characteristic of this } \\
\text { type of product, } \\
\text { slightly sweetish } \\
\text { (5 points) }\end{array}$ & $\begin{array}{l}\text { characteristic of this } \\
\text { type of product, } \\
\text { slightly sweetish } \\
\text { (5 points) }\end{array}$ \\
\hline Smell & $\begin{array}{l}\text { characteristic of wheat } \\
\text { bread, without strange } \\
\text { smells } \\
\text { (4.6 points) }\end{array}$ & $\begin{array}{l}\text { characteristic of the } \\
\text { added flavourings, } \\
\text { without strange smells } \\
\text { (4.2 points) }\end{array}$ & $\begin{array}{l}\text { characteristic of the } \\
\text { added flavourings, } \\
\text { without strange smells } \\
\text { (4.9 points) }\end{array}$ \\
\hline Total points & 35.2 & 37.5 & 39.1 \\
\hline
\end{tabular}

Figure 1 shows bread samples.

During the study, it was found that all samples are of sufficient quality. At the same time samples No. 1 and No. 2 had high organoleptic characteristics. The products had a regular shape, with a slightly convex upper crust for sample no. 1 and more convex for sample no. 2. Samples no 1 and no 2 have pleasant taste and smell. The crumb is baked, not wet to the touch, elastic. Only sample No. 1 had a small amount of holes and the crumb is slightly darker than that of sample No. 2. Due to the active work of rice flour enzymes, the dough is very sticky, and the crumb has a dark colour with uneven porosity.

Soaking the apple pomace in corn oil before making the dough made it possible to obtain bread with developed porosity and good volume. Moisture loss is slower. Therefore, the bread remains fresh after 72 hours and does not go stale. 


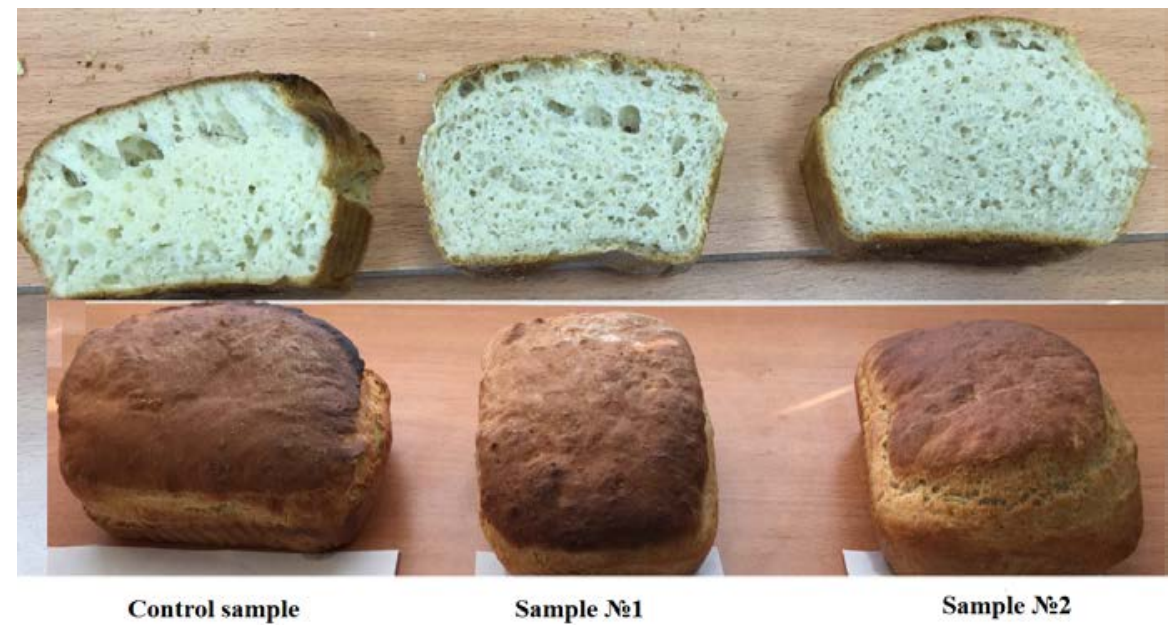

Fig. 1. Bread samples

The use of rice flour in the amount of $10 \%-50 \%$ increases the autolytic activity of wheat flour. The higher autolytic activity of wheat flour indicates an increased activity of enzymes, in particular $\alpha$-amylase. This further negatively affects the quality of the baked product [18].

When more than $20 \%$ of rice flour is added to the dough recipe, there is a deterioration in the elasticity of the dough and darkening of the crumb. Cracks and tears appear on the surface of the product. An increase in the dosage of rice flour leads to a deterioration in the rheological and biochemical parameters of the dough. To obtain bread of satisfactory quality with a dosage of rice flour more than $20 \%$, it is necessary to use special acidifying natural additives.

As a result of carrying out physical and chemical tests for baked bread samples using recycled apple raw materials, the data presented in table 4 were obtained.

Table 4. Results of physical and chemical tests for the developed loaves

\begin{tabular}{|l|c|c|c|}
\hline \multicolumn{1}{|c|}{ Name of the indicator } & Control sample & Sample No.1 & Sample No.2 \\
\hline The humidity of the crumb, \% & 42.2 & 43.6 & 43.6 \\
\hline The acidity of the crumb, 5\%, no more & 3.2 & 3.4 & 3.4 \\
\hline Porosity, \%, noless & 69.25 & 73.30 & 73.30 \\
\hline
\end{tabular}

In terms of physical and chemical parameters, bread samples meet the regulatory requirements. The developed bread samples have high porosity and optimum moisture content. These indicators make bread easier to digest.

The degree of acidity increase is determined by the dosage of the introduced product and the acid content in it. In the process of fermentation of the dough, acid accumulation is not intensified, which should be taken into account when developing a technology for the use of apple products in baking.

Minerals are essential for many biological processes in the body, such as action of the nervous system, structural systems, other cellular processes and water balance [19]. The lack of intake of minerals has been correlated with mental impairment, increased disease conditions, and severe malnutrition [20, 21]).

Using a spectrophotometer, we determined the content of iron and phosphorus in the studied samples of bread. Based on the obtained calibration (Figures 2 and 3), the data presented in Table 5 was obtained. 


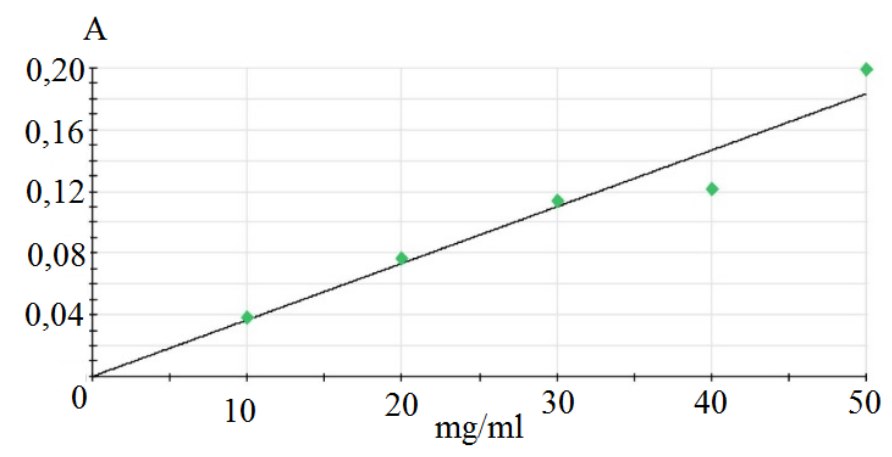

Iron content in bread with rice flour and apples

Fig. 2. Iron concentration in the studied samples of the raw materials used and in the obtained bread samples

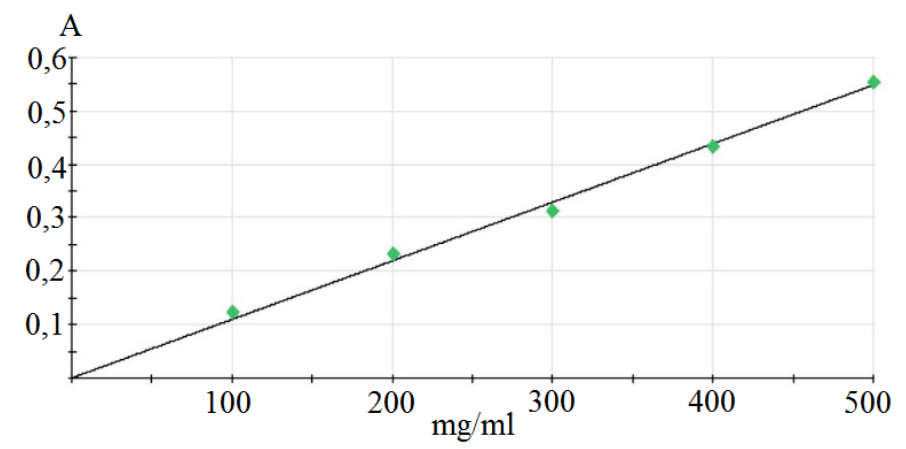

Phosphorus content

Fig. 3. Determination of the concentration of phosphorus in the test samples

Table 5. Content of iron and phosphorus in the test samples

\begin{tabular}{|l|c|c|}
\hline \multicolumn{1}{|c|}{ Samples } & \multicolumn{1}{|c|}{$\begin{array}{c}\text { Iron content, } \\
\mathrm{mg} / 100 \mathrm{~g}\end{array}$} & $\begin{array}{c}\text { Phosphorus content, } \\
\mathrm{mg} / 100 \mathrm{~g}\end{array}$ \\
\hline Riceflour & 4.41 & 68.79 \\
\hline Wheat flour of the highest grade & 6.20 & 72.86 \\
\hline Apple pomace & 6.03 & 79.91 \\
\hline Control bread sample & 3.36 & 47.82 \\
\hline Bread sample No.1 & 3.96 & 55.36 \\
\hline Bread sample No.2 & 4.43 & 56.40 \\
\hline
\end{tabular}

Iron in combination with protein, vitamins, chlorophyll and silicic acid stimulates carbohydrate and protein metabolism, which is accompanied by an increase in the tone of the cardiovascular, respiratory and other body systems, contributes to an increase in the hemoglobin content in the blood and the number of erythrocytes [22, 23].

Analysis of the samples of bread and raw materials used for the content of iron and phosphorus showed that the highest content of this trace element is in sample No. 2. Sample No. 1 in terms of the content of these elements exceeded the control, but is inferior to sample No. 2. When analysing iron in raw materials, it was determined that its greatest amount is contained in wheat flour, the smallest amount in rice. Apple pomace in terms of iron content is close to wheat flour. The highest phosphorus content is observed in apple pomace, and the lowest in rice flour. 


\section{Conclusions}

The results of this work showed that bread containing $10 \%$ apple pomace and $25 \%$ rice flour (sample No. 1), $10 \%$ apple pomace, $12.5 \%$ rice flour (sample No. 2 ), is superior in quality to bread made from $100 \%$ wheat flour. Sample no 2 was more palatable in taste, texture, aroma, colour and crumb. Sample No. 1 was no worse than sample No. 2 in terms of organoleptic characteristics. It only had holes in the structure.

The use of wheat flour and apple pomace in the manufacture of bread affects the increase in the content of iron and phosphorus in the finished product.

According to the data obtained as a result of this work, recipes containing apple pomace and wheat flour produce high quality bread.

\section{References}

1. I.S. Kotsianis, V. Giannou, C. Tzia Trends Food Sci. Technol 13, 319 (2002)

2. S.G. Motrena, M.J. Carvalho, J. Canada, N.B. Alvarenga, F.C. Lidon, B.P. Elisa Recent Res. Sci. Technol. 3, 64 (2011)

3. C. Helou, P. Gadonna-Widehem, N. Robert, G. Branlard, J. Thebault, S. Librere, S. Jacquot, J. Mardon, A. Piquet-Pissaloux, S. Chapron, A. Chatillon, C. Niquet-Léridon, F.J. Tessier. Food Funct 7 (6), 2498 (2016)

4. A.S. Sivam, D. Sun-Waterhouse, S. Quek, C.O. Perera. FoodSci., 75 (8), R163 (2010)

5. A.K. Madbouly, A.M. Kamal, A. Elyousr, I.M. Ismail. Biological Control 144 (5), 104239 (2020)

6. G. Hashem, A. Fernandez-Gonzalezc, M.E. Diaz Garciac. Food Hydrocolloids 108 (11), 105806 (2020)

7. Y.D. García, B.S. Valles, A.P. Lobo. Food Chemistry 117 (4), 731 (2009)

8. K.B. Pandey, S.I. Rizvi Oxidative medicine and cellular longevity 2 (5), 270 (2009)

9. H. Rasouli, M.H. Farzaei, R. Khodarahmi. International Journal of Food Properties 20 (sup2), 1700 (2017)

10. J. Vulić, V. Šeregelj, A. Kalušević, S. Lević, V. Nedović, V.T. Šaponjac, et al. Molecules, 24, 2837 (2019)

11. P.A. Chaldaev, A.Yu. Svechnikov. Food industry V. 4., 23 (2014)

12. A.G. Petrova, N.S. Baroyan, A.G. Belyaev Sbornik statei V Mezhdunarodnoi konferentsii v oblasti tovarovedeniia i ekspertizy tovarov «Problemy identifikatsii, kachestva i konkurentosposobnosti potrebitelskikh tovarov» 221 (2017)

13. S. Makhoul, A. Romano, V. Capozzi, G. Spano et al. Food Sci. Technol. V. 8. No 9, 1925 (2015)

14. S.W. Horstmann, J.J. Atzler, M. Heitmann, E. Zannini et al. European Food Research and Technology 13 (2018)

15. E.A. Pianikova, A.E. Kovaleva, A.S. Ryazantseva Technologies for the food and processing industry of AIC - healthyfood No. 2, 65 (2020)

16. AOAC, 2000. Official Methods of Analysis. 17th ed. Association of Official Analytical Chemists, AOAC International, Arlington, VA.

17. A.E. Kovaleva, E.A. Pyanikova, E.I. Bykovskaya, E.V. Ovchinnikova. Vestnik VGUIT vol. 81. no. 4, 122 (2019)

18. D. T. Hien Food industry No.6., 64 (2010)

19. M.O. Ameh, D.I. Gernah, B.D. Igbabul. Food Nutr. Sci. 4, 43 (2013)

20. A.J. Shubhangini Google Scholar (2002)

21. F.O. Abulude Food J. 23, 139 (2005)

22. PJ. Iron Aggett, J.W. Erdman, I.A. Macdonald, S.H. Zeisel, eds. Wiley-Blackwell 506 (2012)

23. L.E. Murray-Kolbe, J. Beard Iron et al. 2nd ed. London and New York: Inform a Healthcare, 432 (2010) 